Discussion Paper No. 07-029

\title{
Is the Welfare State Self-destructive? A Study of Government Benefit Morale
}

Friedrich Heinemann

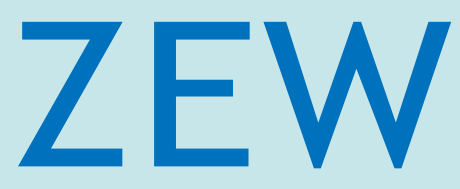

Zentrum für Europäische Wirtschaftsforschung $\mathrm{GmbH}$

Centre for European

Economic Research 
Discussion Paper No. 07-029

\title{
Is the Welfare State Self-destructive? A Study of Government Benefit Morale
}

\author{
Friedrich Heinemann
}

Download this ZEW Discussion Paper from our ftp server:

ftp://ftp.zew.de/pub/zew-docs/dp/dp07030.pdf

Die Discussion Papers dienen einer möglichst schnellen Verbreitung von neueren Forschungsarbeiten des ZEW. Die Beiträge liegen in alleiniger Verantwortung der Autoren und stellen nicht notwendigerweise die Meinung des ZEW dar.

Discussion Papers are intended to make results of ZEW research promptly available to other economists in order to encourage discussion and suggestions for revisions. The authors are solely responsible for the contents which do not necessarily represent the opinion of the ZEW. 


\section{Non-technical summary}

Social norms are increasingly acknowledged in economic analysis to be part of the restrictions which should be taken account for a full understanding of observable behavioural patterns. However, in the field of public finance only a gradual inclusion of prevalent norms in explanatory approaches is taking place. Whereas tax morale, for example, has attracted growing attention in attempts to explain observable tax compliance other norms relevant for public finances have been neglected. This is particularly relevant for social norms with relevance for the functioning of the welfare state. This study contributes to overcome that gap.

Social norms can be expected to be of large importance for the costs of welfare state institutions. Generous support systems for the unemployed are less costly if people see it as their obligation to care for themselves or attach a "stigma" to the acceptance of benefits. Conversely, the emergence of transfer dependency as an accepted model of economic life would make a given benefit scheme more expensive both in fiscal terms and with regard to the relevance of labour supply disincentives. For example, social norms about the use of social benefits may affect the tendency to apply for social assistance, job search intensity and the level of reservation wages, workers' absenteeism or applications for early retirement.

The dynamics of benefit morale which had been touched upon only casually in the few empirical studies on benefit morale is a particular interesting and important aspect. A stable downward trend in benefit morale would be a serious concern for the stability of the welfare state which anyhow faces increasing challenges from ageing and global competition. In a number of contributions, Assar Lindbeck and co-authors have pointed out that the welfare state due to "hazardous dynamics" may "destroy its own economic foundation". One of the channels Lindbeck identifies is the impact the welfare state itself has on benefit morale. In essence, he fears that a generous welfare state undermines the very social norms which are indispensable for its proper functioning. It is the objective of this paper to study the empirical contents of Lindbeck's hypothesis and to contribute to a better understanding of the dynamics of benefit morale. On the basis of results from the World Value Survey the question is addressed whether a country's welfare state history determines its present degree of benefit morale.

The results support Lindbeck's concerns: The build-up of the welfare state and increasing unemployment tend to impair relevant ethical standards. The presented empirical findings clearly indicate that Assar Lindbeck's theory on self-destructive welfare state dynamics has empirical backing. Social norms which safeguard the welfare state's stability and limit its costs appear to be influenced by the welfare state's history. Specifically, transfer expansion or increasing unemployment tend to be associated with a larger readiness of the country's population to cheat on benefits. These findings have implications for the 
design of welfare state reforms. Furthermore, they highlight the risk that conventional empirical approaches to measure the incentive effects of welfare state arrangements may underestimate the strength of incentive effects in the long-run.

With regard to welfare state reforms the conclusion is that the large variance in benefit morale must not be ignored in the design of reform options for the welfare state. An imitation of institutions which have proven viable in countries with high ethical standards can fail in a country with low ethical standards. Therefore, different social norms have to be taken into account in reflections on imitation strategies based on learning from successful countries. A further conclusion is that the problem of a potential "welfare state overshoot" as identified theoretically by Lindbeck may indeed be relevant empirically: If only short-run incentive effects are accounted for in the decision on the build-up of welfare state arrangements then the long-run costs of the welfare state are underestimated. The decision based on the short-run calculus will then be more generous than it would be the case if the optimizing calculus was based on a full account of all (also the long-run) behavioural reactions which result from the welfare state's gradual impact on social norms.

Besides these economic policy insights methodological conclusions emerge. Standard microeconometric approaches targeted at the quantification of incentive effects are based on the implicit assumption of stable social norms. E.g., in the context of labour markets normative restrictions with regard to the take-up of social benefits are treated as exogenously given. This study stresses the problem that this ceteris paribus assumption is empirically not valid. If transfers undermine those norms which support a reluctant takeup of government benefits then the negative effects of transfers on labour supply are more pronounced than it can be measured in the standard microeconometric exercises. 


\title{
Is the Welfare State Self-destructive? A Study of Government Benefit Morale
}

\author{
Friedrich Heinemann \\ Centre for European Economic Research (ZEW)
}

May 2007

\begin{abstract}
Assar Lindbeck has pointed to the problem that generous welfare state institutions may in the long-run undermine those social norms which limit the costs and incentives effects of the welfare state and thus guarantee its viability. This study is the first to assess the empirical validity of Lindbeck's notion by assessing the long-run link between the welfare state and social norms with regard to the honest take-up of government benefits. Based on the results of four waves of the World Value Surveys the determinants of benefit morale - defined as the reluctance to claim government benefits without legal entitlement - are analysed. Besides a standard list of the respondents' individual characteristics, macroeconomic indicators describing a country's long-run welfare state and labour market history are included. The results support the empirical validity of Lindbeck's theory: An increase of government benefits and unemployment is in the long-run associated with deteriorating welfare state ethics.
\end{abstract}

Acknowledgement: Able research assistance by Benjamin Tanz and Björn Siggemann and helpful comments from participants of the World Meeting of the Public Choice Society in Amsterdam 2007 and of the Research Seminar of the Freie Universität Berlin are gratefully acknowledged.

JEL-Classification: Z 13, I 30, I 38,

Keywords: benefit morale, tax morale, welfare state reforms

P.O. Box 103443

68034 Mannheim

Germany
Phone +49621 1235149

Fax +496211235 223

Email heinemann@zew.de 


\section{Introduction}

In public economics it has become popular to take account of social norms in order to better understand the functioning of institutions. Increasingly, it is accepted that common habits and values must not be ignored to understand the behaviour of citizens for example with regard to the observable degree of tax compliance (Torgler, 2002). Obviously, citizens in many public policy contexts do not act as if they were maximizing their narrow self-interest without paying tribute to society's views on what is an acceptable behaviour.

Social norms can be expected to be particularly relevant for the effectiveness of the welfare state. Generous support systems for the unemployed are less costly if people see it as their obligation to care for themselves or attach a "stigma" to the acceptance of benefits. Conversely, common views that everybody has a moral right to receive government benefits or the emergence of transfer dependency as a normal model of economic life would make a given benefit scheme more expensive both in fiscal terms and with regard to the relevance of labour supply disincentives. For example, social norms about the use of social benefits may affect the tendency to apply for social assistance, job search intensity and the level of reservation wages, workers' absenteeism or applications for early retirement (Lindbeck, 1995a).

While a substantial body of literature has evolved with regard to tax morale, benefit morale so far is an empirically largely neglected issue. Algan and Cahuc (2005) and Halla and Schneider (2005) are rare exceptions. Algan and Cahuc (2005) study benefit morale in the context of the debate on European reform models for the labour market. They stress the fact that the prevalent civic attitudes with regard to claiming government benefits are an important restriction when a country chooses and adapts its labour market institutions. On the basis of empirical insights from the World Value Surveys, the authors look at the much discussed Danish model which combines low standards of employment protection with high standards of unemployment benefits. They argue that this "flexicurity" model fits well to the outstandingly high benefit morale of the Danes but would be inappropriate for countries where a much larger share of the population is willing to cheat on benefits. The authors conclude that country factors are much more important to understand an individual's morale than standard socio-economic factors and link these country effects to "culture". In their analysis, Algan and Cahuc do not look at evolution of benefit morale over time and, implicitly, regard the country factors as stable.

For Austrian survey data, Halla and Schneider (2005) contrast the determinants of benefit morale with that of tax morale. According to their results, age and employment status affect benefit but not tax morale. Family status, religion, education, income and trust in the legal system are among the significant drivers of tax morale, but not of benefit morale. 
Furthermore, the results indicate that benefit morale indeed affects the degree to which benefits are claimed without justification whereas the link between tax morale and actual tax evasion is less clear cut. The authors also mention that, in general, benefit morale had deteriorated in Austria over the nineties while tax morale was stable, however, without paying attention to explanations behind that dynamics.

The dynamics of benefit morale which had been touched upon only casually in the few empirical studies on benefit morale is a particular interesting and important aspect. A stable downward trend in benefit morale would be a serious concern for the stability of the welfare state which anyhow faces increasing challenges from ageing and global competition. In a number of contributions, Assar Lindbeck and co-authors (Lindbeck, 1995a,b; Lindbeck et al., 1999; Lindbeck and Nyberg, 2006) have pointed out that the welfare state due to "hazardous dynamics" may "destroy its own economic foundation" (Lindbeck, 1995a, 9). One of the channels Lindbeck identifies is the impact the welfare state itself has on benefit morale. In essence, he fears that a generous welfare state undermines the very social norms which are indispensable for its proper functioning.

It is the objective of this paper to study the empirical contents of Lindbeck's hypothesis and to contribute to a better understanding of the dynamics of benefit morale. On the basis of results from the World Value the question is addressed whether a country's welfare state history determines its present degree of benefit morale.

The results support Lindbeck's concerns: The build-up of the welfare state and increasing unemployment tend to impair relevant ethical standards. The findings suggest that longrun fiscal cost and disincentive effects of any welfare state expansion are more substantial than short-run effects. Hence, disincentives as measured in standard microeconometric approaches may underestimate the long-run severity of the problem.

The structure of the paper is as follows: In section 2 the theoretical arguments proposed by Lindbeck and others on the potential drivers of benefit morale are developed and testable hypotheses with a particular focus on the long-run dynamics are derived. Section 3 includes some descriptive evidence on the link between the history of a country's welfare state and the benefit morale of its population. Section 4 presents the results of econometric testing combining socio-economic characteristics with welfare state related and other country effects among the determinants of individual benefit morale in OECD countries. Section 5 concludes. 


\section{The dynamics of welfare state social norms: theory}

Social norms can constrain the behaviour of agents because breaking such norms creates discomfort (Parsons, 1952, Lindbeck, 1995b). These psychological costs of breaking unwritten rules can explain that people do not steal, do not evade taxes or do not cheat on benefits even if from a narrow rational view this would constitute optimizing behaviour given low detection probabilities and limited sanctions. Hence, social norms with regard to the welfare state which, for example, imply a high esteem for transfer independence provide a normative check against disincentive effects in a social transfer system.

Welfare state norms need not be stable over time. In his analysis of "hazardous welfarestate dynamics", Lindbeck $(1995 a, b)$ points to possible processes over which a more generous welfare state can - in the long run - have a detrimental impact on these norms. From the individual perspective, the introduction of more generous transfer schemes will make it more expensive to stick to any established norm which implies a negative valuation of receiving benefits ${ }^{1}$. This may have no immediate consequences for the large majority of people but some individuals could abandon the dominating habits, prove to be individually successful with this new type of behaviour and subsequently and steadily followed by imitators (Sugden, 1986). At a certain moment in this process a "critical mass" of people can be reached so that the social norm ceases to be supported in general because the perception of other citizens' behaviour is being affected. Norms are supported by reciprocity: if an individual perceives that others (friends, neighbours, society as a whole) do not stick to that norm, that individual will be likely to abandon this norm as well.

Lindbeck suspects that a macroeconomic shock can function as a catalyst to changing welfare state norms. Negative macroeconomic shocks generating a sudden hike in unemployment abruptly confronts a high number of individuals with different welfare systems and thus can create the critical mass of transfer recipients necessary to transform pre-existing social norms. This suggests that not the institutional characteristics of a welfare system alone but also the objective need of a large number of citizens to get help from these safety nets can be drivers of benefit morale.

A further catalyst for changing norms according to Lindbeck's exposition is generational change. Lindbeck suggests that each generation's values and norms are created by the incentive structures in the specific generation's younger years and that these convictions

1 It is not essential whether the pre-existing social norm only implies a negative assessment of cheating on benefits or also a negative view even at claiming legally justified benefits. 
tend to be relatively stable for the rest of any generation's life. If this is so, the transformation of social norms as a consequence of an expansion of the welfare state will be substantially delayed because only with the socialization of new birth cohorts the change in values will materialize. In this context, Lindbeck and Nyberg (2006) point to the negative effect generous welfare state norms have on parents' incentives to instill work norms in their children. In this sense the welfare state may have an impact on education and thus - with a time lag of a generation - affect behaviour of people of working age.

If these negative and strongly delayed links between the welfare state itself and social norms on benefits are empirically valid this creates the problem of a "welfare overshoot" (Lindbeck, 1995a,b): Politicians who choose welfare state arrangements as a result of a short-run calculus will install more generous arrangements than they would if they took account of the long-run incentive effects.

Lindbeck's "hazardous welfare state dynamics" is open for empirical testing. Test strategies may be indirect or direct. Direct approaches look immediately into the drivers of social norms whereas indirect strategies check whether certain developments are consistent with an erosion of social norms driven by the welfare state's generosity. In a recent contribution, Lindbeck and Nyberg (2006) give an example of such an indirect testing strategy and link the decline in average hours worked in Europe since the mid-70s to the increasing generosity of welfare state arrangements which, with a considerable time lag, may have led to the erosion of work norms.

Here, the direct approach is applied by a straightforward analysis of social norms and their determinants. Lindbeck's theory implies that a country's change in its population's benefit morale should be affected by this country's welfare state history. Countries having experienced a substantial build-up of transfers should also be countries with deteriorating benefit morale. Note that a negative contemporaneous correlation between the size of the welfare state and benefit morale cannot be expected. As Algan and Cahuc (2005) convincingly argue and show this contemporaneous correlation is rather positive because high benefit morale is a precondition that a generous social support system can be implemented. However, the expansion of the welfare state should according to Lindbeck's theory impair the, initially, high social morale. Thus, a testable hypothesis is:

Hypothesis 1: The expansion of the welfare state over the last decades has led to lower levels of benefit morale over this period.

Second, in addition to the evolution of welfare state institutions, unfavourable macroeconomic developments and increasing unemployment, in particular, should leave negative traces on benefit morale.

Hypothesis 2: The change of unemployment over the last decades has had a negative impact on benefit morale over this period. 
Third, if Lindbeck's presumption about a specific welfare state norm in each generation holds there should be observable cohort effects corresponding to the build-up of the welfare state in industrial countries. Earlier birth cohorts should have higher levels of benefit morale than later ones. This cohort effect is logically different from a pure age effect which would mean that older have higher morale than younger independent from their birth year (see below).

Hypothesis 3: Earlier birth cohorts of people who had been socialized before the massive build-up of the welfare state should have higher levels of benefit morale than later cohorts.

While hypotheses 1-3 are the focus of this empirical analysis, further hypotheses on the potential impact of a number of individual- and country-specific control variables will be taken account of. The hypotheses with regard to individual-specific characteristics constitute a standard as it has emerged from the literature on the determinants of tax morale (e.g., Alm and Torgler, 2006) and as they have been also included in the few studies on benefit morale as mentioned above (see, in particular, Halla and Schneider, 2005, for further discussion and literature on each of the hypotheses):

- Gender: Females are regularly regarded as more compliant with explicit laws and social norms than males.

- Age: Regularly, older people tend to be more honest than younger people. Reasons discussed include their higher social capital acquired in their life or their more intense attachment to their community.

- Religion: Due to the high esteem for moral behaviour in almost all religions more religious people should also have higher levels of benefit morale.

- Marriage: Married people are more constrained with regard to their social behaviour and their reflections on the validity of social norms than singles and, hence, should have a higher benefit morale.

- Unemployment: Unemployment is an indicator of objective need to take up welfare benefits. It also is a proxy for the familiarity with a situation of being a benefit recipient. Hence, a reluctance to accept benefits is more expensive for unemployed than for the employed so that unemployment should be associated with a lower level of benefit morale.

- Trust: Trust in a country's institutions, be it the government, the parties, the legal system or the parliament, is conducive for cooperative behaviour as the vast literature on social capital has convincingly established.

- Patriotism: Pride in a country supports the readiness to accept this country's rules. As a consequence, a high degree of patriotism should also foster benefit morale. 
- Income: While the theoretical impact of income on tax morale is ambiguous, there is a more straightforward link with regard to benefit morale: With rising income the opportunities to claim (justified or unjustified) government benefits are reduced. Thus, high benefit morale is less costly with high income. Income should, therefore, be a positive driver of benefit morale.

- Financial satisfaction: A high degree of financial satisfaction should lead to higher benefit morale due to two reasons. First, high financial satisfaction in analogy to a high income makes benefit morale less costly. Second, it reduces the feeling of being treated in an unfair way by society and thus supports the acceptance of social norms based on reciprocity considerations ("if the society treats me fair I will keep the rules of that society").

\section{A descriptive look at benefit morale}

The European and World Value Surveys (The European Values Study Foundation and World Values Survey Association, 2006) offer a rich database which allows to study the cross-section properties of dominant views on the welfare state as well as these views' evolution over time. Currently four waves of surveys (wave 1: 1981-1984, wave 2: 19891991, wave 3: 1995-1998 and wave 4: 1999-2001) are available.

The question on benefit morale which stands in this study's focus belongs to the standard list of questions which are covered in all waves and is formulated as follows:

"Please tell me whether you think it can always be justified, never be justified, or something in between claiming government benefits to which you are not entitled". Answers are given on a ten-point scale from 1 ("never justifiable") to 10 (" always justifiable").

It is debatable whether answers to this question can be expected to be always honest. However, Torgler and Werner (2005) defend the data quality with respect to the analogous question on the acceptability of "cheating on taxes". They argue that due to the wide-ranging character of the survey people are not likely to be suspicious about the questions. Indeed, the question is put in a casual way as part of a long questionnaire covering a whole range of issues from religion to politics so that suspicion should be low that this question could be part of a administrative control measure. Furthermore, the question does not relate to actual behaviour so that people are not asked to confess to which extent they actually break normative rules or laws. 
Since the WEVS also includes the standard socio-economic characteristics and questions concerning religious beliefs, confidence in a country's institutions, the extent of pride in the own country and the degree of financial satisfaction it allows to include the above mentioned control variables in the empirical analysis (see Table 1 in the appendix).

In order to search for the impact of a country's welfare state on the change of benefit morale the data set is augmented by two macroeconomic variables. To each observation in the data set the relevant country's 20 -year-change in social security benefits paid by the government relative to GDP and its 20-year-change in the unemployment rate is assigned. The change in spending on social benefits is a comprising proxy for the evolution of the welfare state and, hence, allows testing hypothesis 1 whereas the change in the unemployment rate allows testing hypothesis 2. The 20-year-interval corresponds to the longest available time span of the WEVS data and reaches a length in line with the long-run character of Lindbeck's considerations.

Detrimental welfare state dynamics as they are discussed here are only a meaningful concept in the context of developed industrial countries locking back at a history with a welfare state which already has been present for decades. Therefore, the empirical analysis is confined to WEVS observations from OECD countries (for country coverage see table 2 in the appendix).

Table 1 summarizes analyses of variance for the list of standard explanatory variables presented above. Obviously, all variables are significantly correlated with benefit morale with the sign corresponding to theoretical expectations. Thus, the reluctance to claim benefits without justification is positively correlated with age, attendance of religious services, confidence in the parliament, patriotism, income and financial satisfaction. In addition, it is higher for women than for men, for married than for unmarried and for employed than for unemployed persons.

Table 2 summarizes the development of benefit morale over time for industrial countries. In a majority of countries, the acceptance of illegal benefit claims has increased. This erosion of social norms has been strongest in the case of Sweden. However, there are a number of countries with a remarkable stability of this particular social norm, among them Canada and Western Germany.

Some of the changes over time are certainly driven by exceptional circumstances in the early 90s. For the Czech Republic and Hungary and, in particular, for Finland, extremely low levels of benefit morale have been measured in the World Value Survey's second wave which could be related to the critical labour market situation in these countries in that time. This could cautiously be taken as case study evidence in favour of the view that macroeconomic shocks and job uncertainty impact on the degree of compliance with the welfare state's rules. 
Within Germany, benefit morale has converged between the western and the eastern part of the country. For Western Germany in the fourth wave, the indicator has even reached a higher level compared to the first wave. For Eastern Germany, a declining level was measured resulting in the fourth wave in a slightly lower level compared to Western Germany. This development is consistent with a view that the poor labour market situation in Eastern Germany and the increasing acquaintance with the rules of the welfare state have impaired benefit morale since unification. This type of convergence can be measured in an analogous way for tax morale in Germany (Halla und Schneider, 2005). 
Table 1: Analysis of variance for benefit morale: Individual characteristics

\begin{tabular}{|c|c|c|c|c|}
\hline Variable & & $\begin{array}{l}\text { Share of high } \\
\text { benefit } \\
\text { morale }^{1}\end{array}$ & $\begin{array}{l}\mathrm{Nb} \text {. } \\
\text { observations }\end{array}$ & F-test \\
\hline \multirow{2}{*}{ Gender } & Male & 0.609 & 55,396 & \\
\hline & Female & 0.645 & 60,694 & $160.34^{\star \star \star}$ \\
\hline \multirow[t]{4}{*}{ Age } & $<=25$ & 0.477 & 20,621 & \\
\hline & $26-40$ & 0.592 & 35,104 & \\
\hline & $41-60$ & 0.675 & 35,818 & \\
\hline & $>60$ & 0.738 & 24,676 & $1314.61^{\star \star \star}$ \\
\hline \multirow[t]{2}{*}{$\begin{array}{l}\text { Attendance of } \\
\text { religious } \\
\text { services }\end{array}$} & $\begin{array}{l}\text { At least once a } \\
\text { month }\end{array}$ & 0.657 & 39,888 & \\
\hline & Less frequently & 0.610 & 73,007 & $244.7^{\star \star \star \star}$ \\
\hline \multirow{2}{*}{ Marital status } & Married & 0.671 & 68,156 & \\
\hline & Not married & 0.567 & 46,700 & $1308.8^{\star \star \star}$ \\
\hline \multirow[t]{2}{*}{ Unemployment } & Unemployed & 0.547 & 5,894 & \\
\hline & Not unemployed & 0.632 & 106,064 & $170.9^{\star \star \star}$ \\
\hline \multirow[t]{2}{*}{$\begin{array}{l}\text { Confidence in } \\
\text { Parliament }\end{array}$} & $\begin{array}{l}\text { Quite a lot or a } \\
\text { great deal }\end{array}$ & 0.646 & 46,697 & \\
\hline & $\begin{array}{l}\text { None at all or not } \\
\text { very }\end{array}$ & 0.613 & 64,622 & $128.7^{\star \star \star}$ \\
\hline \multirow[t]{2}{*}{ Patriotism } & $\begin{array}{l}\text { Very or quite } \\
\text { proud about } \\
\text { nationality }\end{array}$ & 0.642 & 94,805 & \\
\hline & $\begin{array}{l}\text { Not very or not at } \\
\text { all proud }\end{array}$ & 0.559 & 15,689 & $398.8^{\star \star \star}$ \\
\hline \multirow[t]{2}{*}{ Income } & $\begin{array}{l}\text { Upper half of } \\
\text { income shares }\end{array}$ & 0.630 & 39,440 & \\
\hline & $\begin{array}{l}\text { Lower half of } \\
\text { income shares }\end{array}$ & 0.619 & 55,689 & $11.5^{\star \star \star}$ \\
\hline \multirow[t]{2}{*}{$\begin{array}{l}\text { Financial } \\
\text { satisfaction }\end{array}$} & $\begin{array}{l}\text { Upper half of } \\
\text { satisfaction scale }\end{array}$ & 0.661 & 57,776 & \\
\hline & $\begin{array}{l}\text { Lower half of } \\
\text { satisfaction scale }\end{array}$ & 0.594 & 30,387 & $396.2^{\star \star \star}$ \\
\hline
\end{tabular}

${ }^{1}$ High benefit morale defined as answer "claiming government benefits to which you are not entitled is never justifiable"; ***: 1 percent significance level. 
Table 2: Benefit morale* per country over time

\begin{tabular}{|c|c|c|c|c|}
\hline & \multicolumn{4}{|c|}{ Wave } \\
\hline & 1 & 2 & 3 & 4 \\
\hline & 1981-84 & $1989-1993$ & 1994-1999 & $1999-2004$ \\
\hline Australia & 0.740 & & 0.739 & \\
\hline Austria & & 0.687 & & 0.595 \\
\hline Belgium & 0.664 & 0.524 & & 0.543 \\
\hline Canada & 0.612 & 0.695 & & 0.714 \\
\hline Czech Republic & & 0.497 & 0.454 & 0.650 \\
\hline Denmark & 0.896 & 0.808 & & 0.833 \\
\hline Finland & & 0.126 & 0.627 & 0.494 \\
\hline France & 0.389 & 0.383 & & 0.408 \\
\hline Greece & & & & 0.240 \\
\hline Hungary & 0.818 & 0.612 & 0.546 & 0.759 \\
\hline Iceland & 0.732 & 0.721 & & 0.680 \\
\hline Ireland & 0.721 & 0.683 & & 0.698 \\
\hline Italy & 0.827 & 0.658 & & 0.649 \\
\hline Japan & 0.680 & 0.668 & 0.642 & 0.644 \\
\hline Korea & 0.630 & 0.770 & & \\
\hline Luxembourg & & & & 0.457 \\
\hline Mexiko & & 0.217 & 0.489 & 0.448 \\
\hline Netherlands & 0.818 & 0.736 & & 0.775 \\
\hline New Zealand & & & 0.703 & \\
\hline Norway & 0.803 & 0.794 & 0.709 & \\
\hline Poland & & 0.633 & 0.552 & 0.536 \\
\hline Portugal & & 0.537 & & 0.586 \\
\hline Slovakia & & 0.426 & 0.340 & 0.374 \\
\hline Spain & 0.600 & 0.610 & 0.668 & 0.560 \\
\hline Sweden & 0.815 & 0.745 & 0.579 & 0.553 \\
\hline Switzerland & & 0.732 & 0.618 & \\
\hline Turkey & & 0.831 & & 0.898 \\
\hline Great Britain & 0.729 & 0.686 & & 0.657 \\
\hline United States & 0.760 & 0.678 & 0.758 & 0.641 \\
\hline West Germany & 0.615 & 0.559 & 0.575 & 0.648 \\
\hline East Germany & & 0.739 & 0.658 & 0.624 \\
\hline
\end{tabular}

*Respondents' share of answer "claiming government benefits to which you are not entitled is never justifiable"; missing values: country not covered in the respective wave. 
Looking at the correlation between the size of the welfare state and benefit morale counteracting effects have to be taken into consideration. As argued in the literature (Algan and Cahuc, 2005), the population's readiness to comply with the rules of the system is a determinant of the system's optimum generosity: Hence, countries with high ethical standards can afford to install more generous benefit schemes, an aspect suggesting a positive correlation. Contrary to that, Lindbeck's "hazardous welfare dynamics" hint towards a negative correlation because the system's degree of generosity impairs ethical standards of a country's citizens. However, the latter aspect should result in a negative correlation of differences: Even if there is a positive correlation of the size of the welfare state and benefit morale a build-up of the welfare state should lead to a falling benefit morale in the long run.

In order to look into these long-run links descriptively, 20-year-differences (or the maximum available time span given missing values in the WVS) of benefit morale and welfare state proxies are presented. A negative correlation can be detected for the differences of benefit morale and unemployment (Figure 2) but not for the differences of benefit morale and the ratio of social spending and GDP (Figure 1). Dropping the outlier Finland due to its exceptional circumstances as discussed the correlation between the 20-year-changes of benefit morale and unemployment is -0.24 while the correlation is slightly positive in the case of the social spending ratio (+0.08 without Finland). This suggests that the unemployment channel is more important compared to the size of social spending for undermining welfare state norms. Thus, this first descriptive evidence rather supports hypothesis 2 than hypothesis 1 . 
Figure 1: Change in benefit morale and change social security benefits/GDP between 1980 and 2000

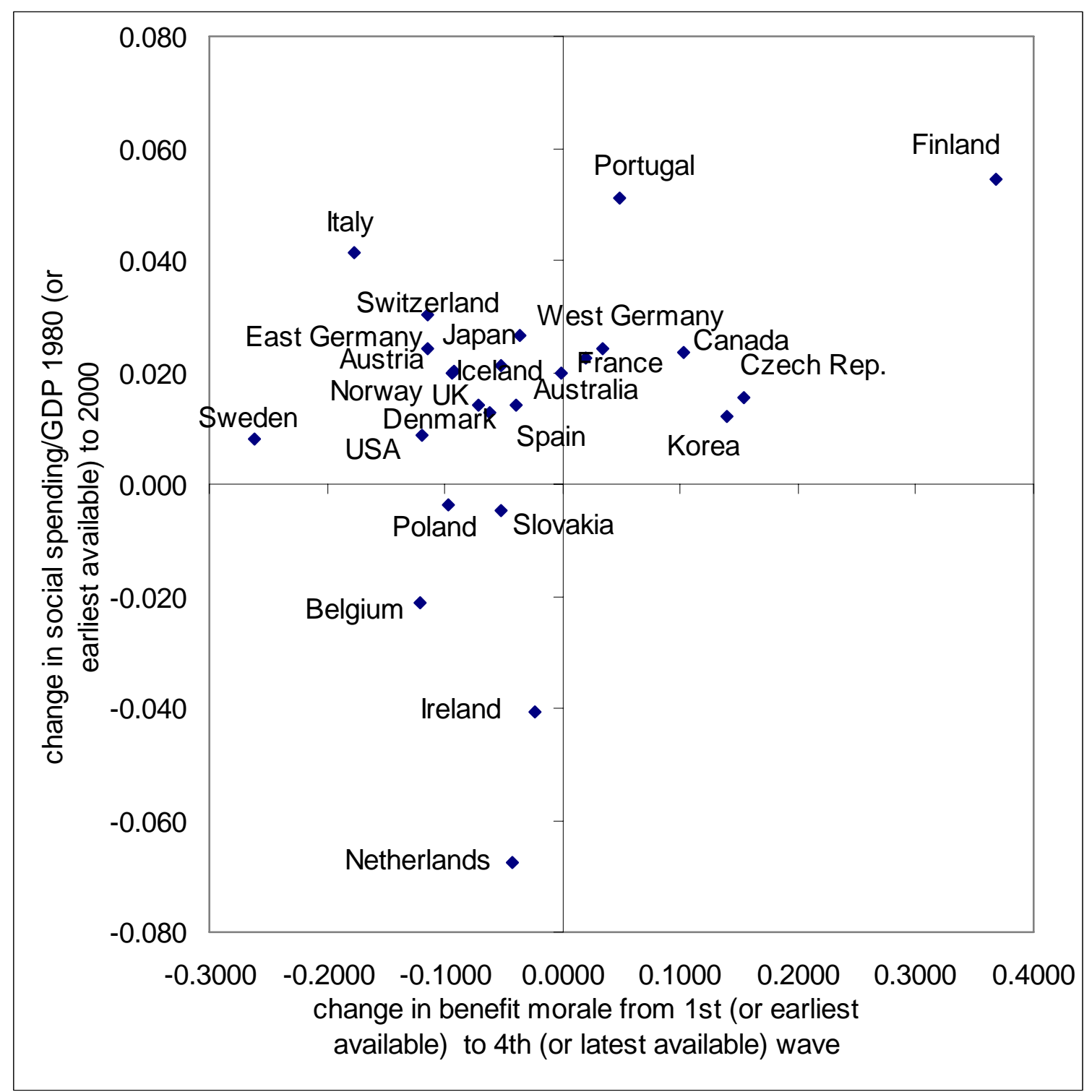


Figure 2: Change in benefit morale change in unemployment between 1980 and 2000

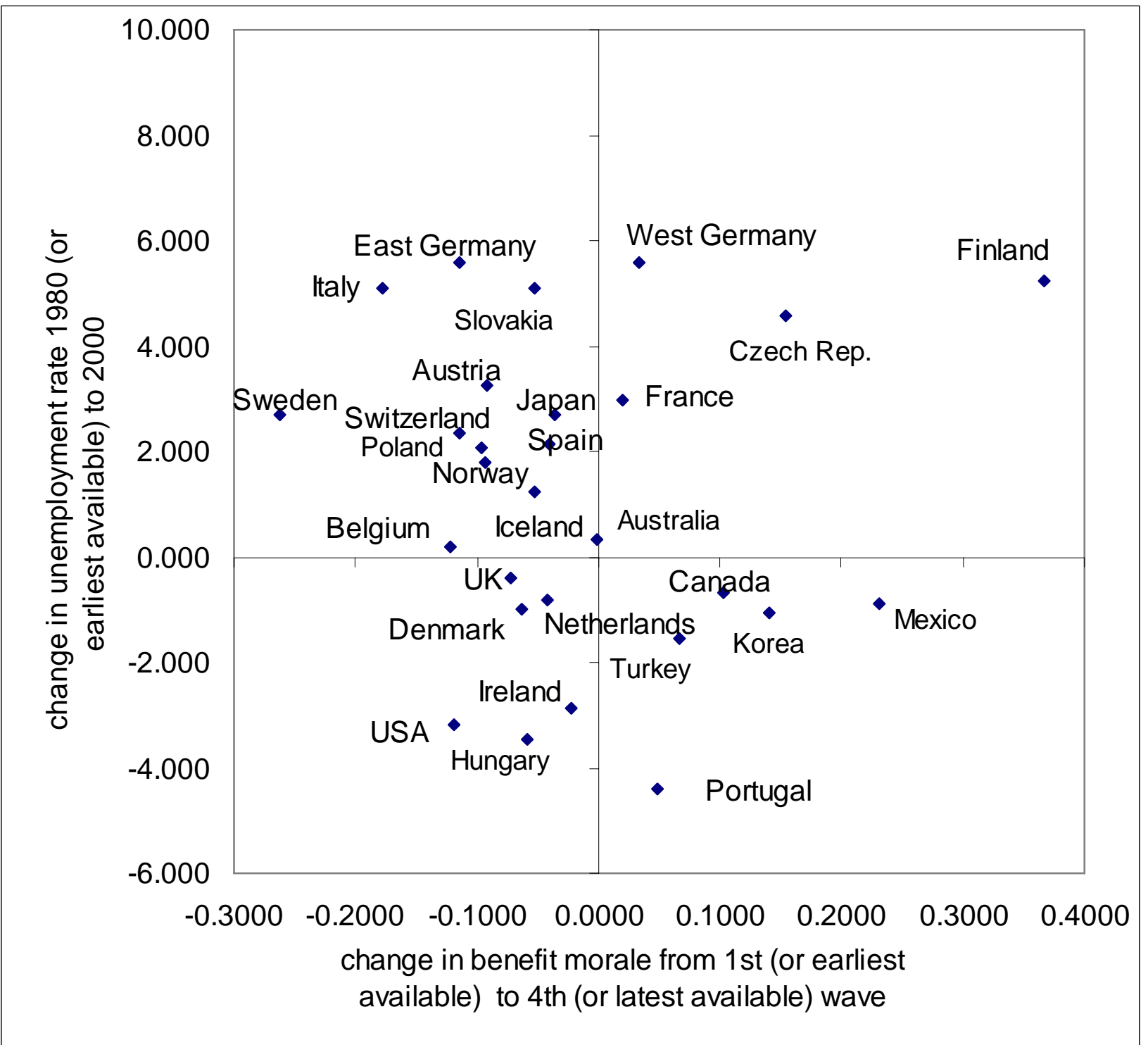


A first descriptive plausibility check can also be applied with regard to hypothesis 3 which claims an impact of the year of birth on benefit morale in addition to a pure age effect. Figure 3 presents age dependent benefit morale - again defined as the share of respondents for which the illegal claim of government benefits is by no means justifiable for four different birth cohorts and depending on the age of respondents. Thus, this depiction allows comparing people from different birth years at the same age. Where overlapping age profiles for different birth cohorts are available this helps to find out whether there are pure cohort effects. Indeed, this analysis supports the empirical relevance of hypothesis 3: The age profiles of different birth cohorts only have two intersections. Apart from these the age profile of the earlier cohort always runs above the age profile of later cohorts. Obviously, benefit morale is declining with an increasing year of birth - independently from age effects. Of course, this depiction is unable to prove whether this is related to the fact that earlier birth cohorts had been socialized in an environment of an infant welfare state. At least, however, these findings are not inconsistent with a key element of Lindbeck's theory.

Figure 3: Age profiles of benefit morale for different birth cohorts

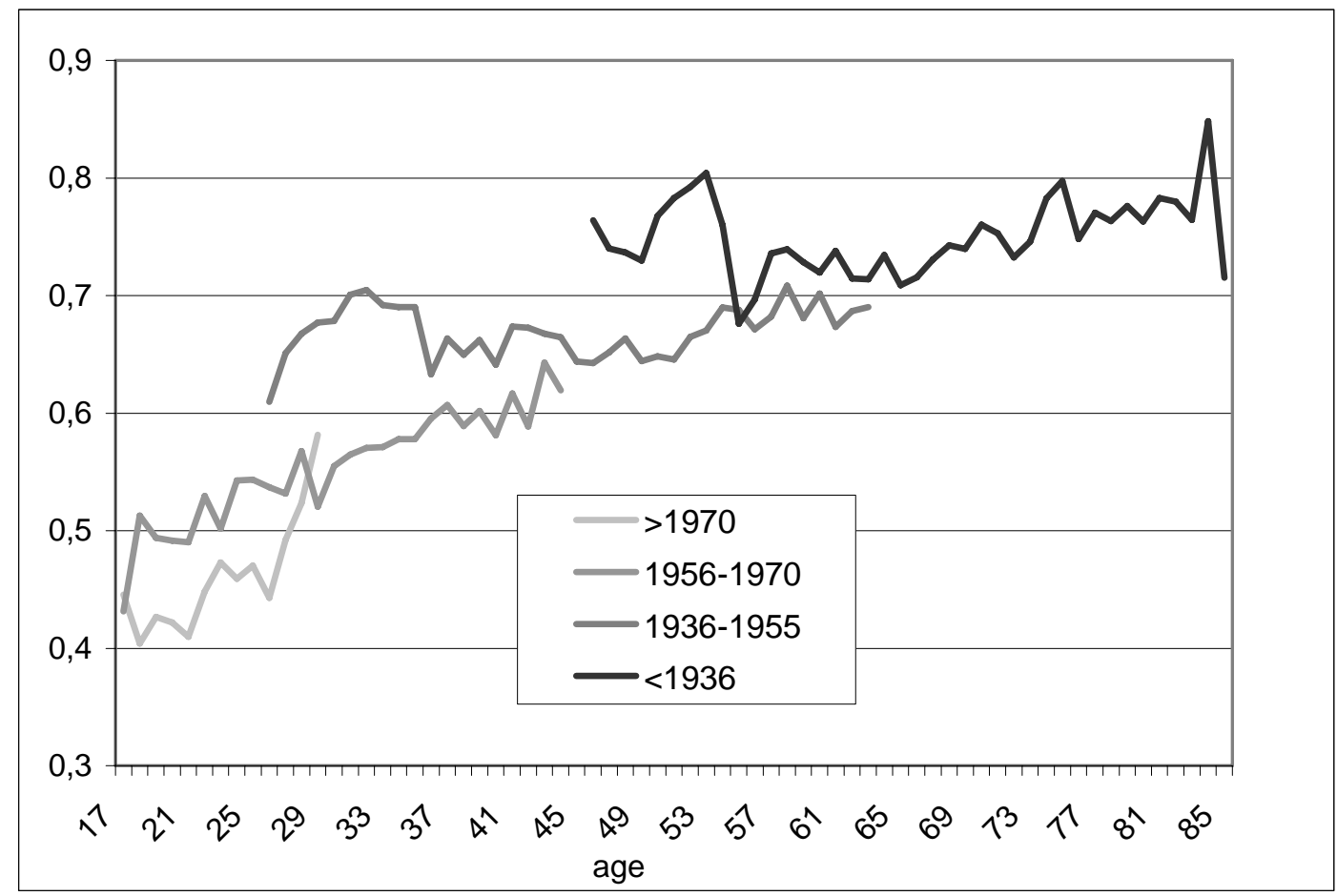

Respondents' mean share of answer "claiming government benefits to which you are not entitled is never justifiable". Means only reported if a minimum of 100 observations in an age-cohort-combination. 


\section{Econometric evidence}

The descriptive insights above offer insightful plausibility checks but may be distorted by other determinants of benefit morale. In the following, regression evidence is presented taking account of the individual characteristics of respondents in addition to the country's welfare state environment. The model is specified in the following way:

(1) $B M_{i}=\beta_{0}+\beta_{1} \triangle W E L F A R E_{C}+\beta_{2} I N D C T L_{i}+\beta_{3}$ COUNTRYCTL $C+\beta_{4} T D+\varepsilon_{i}$

(2) $B M_{i}=\beta_{0}+\beta_{1} \Delta U N E M P L_{C}+\beta_{2} I N D C T L_{i}+\beta_{3} C O U N T R Y C T L_{C}+\beta_{4} T D+\varepsilon_{i}$

An individual's benefit morale is modelled as a function of individual-specific control variables (INDCTL) and two types of country-specific characteristics: the country characteristics referring to Lindbeck's theory (change in welfare state spending in equation 1 and change in unemployment in equation 2) and further country characteristics (COUNTRYCTL) depicting additional country features which may influence benefit morale priori. Finally the model allows for time fixed effects by including the time dummies TD identifying the World Value Survey's wave. Country fixed effects are incompatible with the inclusion of non time-variant country characteristics.

This model is tested on the basis of probit approach focusing on the top answer category of respective question in the World Value Survey ("claiming government benefits to which you are not entitled is never justifiable" versus other answers). All variables listed in Table 1 are included as explanatory variables among the individual-specific characteristics with the exception of the variable "financial satisfaction" which is dropped due to too many missing observations. In order to test hypothesis 3 both the year of birth and the age of the respondent is included. With regard to the employment status different specifications of the relevant variable have been tried. Since a pure unemployment dummy did not show up significantly a modified dummy is included contrasting an employment situation with different forms of non-employment including unemployed, students, housewifes and retired persons.

$\triangle W E L F A R E_{C}$ is quantified as 20-year-difference of the ratio of social benefits to GDP and $\triangle U N E M P L_{C}$ as 20-year-difference in the unemployment rate. Hence, a long-run definition is chosen which comes close to the idea of the theory that long-run changes are essential to undermine pre-existent social norms.

A country's welfare state and labour market history are not the only country factors which may impact on benefit morale. Hence, coefficients of "Lindbeck-variables" included in isolation could be influenced by omitted country variables. This risk is reduced by the additional inclusion of further country characteristics for which a link to the level of benefit morale can be expected. The following aspects are covered by the variables in COUNTRYCTL: 
- Decentralization: The degree of a country's decentralization is an important candidate in this context: In the context of tax morale a positive impact of decentralization has been indicated in the context of Switzerland (Torgler, 2004) and Germany (Torgler and Werner, 2005). The authors interpret the positive sign by referring to the closer interaction between citizens and the state fostering mutual trust and the willingness to obey to rules. In addition the classical fiscal federalism argument that decentralized structures allow a better match between voters' preferences and public good provision should also lead to a more positive view of citizens on the government compared to highly centralized structures. Similar effects as in the case of tax morale cannot be excluded for the link between decentralization and benefit morale. Two decentralization indicators are included: A dummy for the existence of autonomous regions is taken from Beck et al. (2001) and a second indicator focusing on tax decentralization originates from Stegarescu (2005).

- Legal origin: In a growing number of contributions a country's legal origin is identified to be a determinant of the quality of institutions and of growth potential (La Porta et al., 1999). A country's legal origin may also have a lasting impact on the way social norms with regard to keeping a country's rule have developed in the long-run. Hence, this type of variables offers a further way to measure important country characteristics.

- Other standard country-specific variables: Both the geographical position and the degree of ethnic fractionalization play a certain role in cross-section studies of growth potential or quality of government (La Porta et al., 1999; Alesina and Ferrara, 2005). Hence, these variables are included as further country-specific control variables without having strong a priori expectations about these variables's impact on benefit morale. Here, the geographical position is measured as latitude and specifically as the absolute value of the latitude of the capital of the country, scaled to take values between 0 and 1. Source (Djankov et al., 2003, from CIA factbook). Ethnic fractionalization is computed as one minus the Herfindahl index of ethnic group shares. This calculation considers the probability that two persons, randomly chosen, from a population belong to different groups (Alesina et al., 2003).

The estimation procedure deals with a number of problems which could lead to erroneous inference with standard procedures. First, weighted probit estimations are used with weights correcting deviations of the world value survey sampling from the national population's characteristics. Second, the standard assumption of an independent error terms is questionable for observations from an identical country. Unobservable countrycharacteristics are likely to lead to residuals being correlated within one country. To cope with that problem clustered regression technique is applied where the assumption of independent error terms only refers to the across country dimension so that the presented inference is robust to within country correlation of error terms. Wave dummies 
measuring the impact of unobserved time-specific factors are included if they prove to be jointly significant at the 5 percent-significance level.

Specification (1) in Table 3a serves as basis specification and still ignores the country specific welfare state proxies. On the basis of 80.000 observations for all four waves the significance of sex, marital status and patriotism is confirmed with the expected sign. The marginal effects inform about an explanatory variable's impact on the probability that the respondent belongs to the group with high benefit morale. For example, female respondents have a four per cent higher probability to associate themselves with a high benefit morale compared to male respondents. For married persons this probability exceeds that of unmarried by almost five per cent.

Specification (2) in Table 3a presents a first test of equation (1) by including the long-run (20-year-) change in a respondent's country's social transfers. In line with expectations the impact on benefit morale is significantly negative with a marginal effect of 1.3 per cent. Specification (3) includes further country controls with interesting insights such as the fact that autonomy of region indeed is associated with substantially higher benefit morale and that English legal origin countries are characterized by significantly higher benefit morale than French or German legal origin countries. What is, however, essential in this augmented estimation is the fact that the Lindbeck variable survives the inclusion of further country controls at even larger significance and with an increasing marginal effect. Specification (4) finally looks into a possible interaction between the year of birth and the development of the welfare state but does not support the idea that generational change is the primary channel for the erosion of benefit morale. Table $3 b$ summarizes the identical specifications where the focus is now on the long-run (20-year-) change in unemployment instead of social transfers with very similar insights: An increase in the unemployment rate is also robustly related to lower morale whether numerous further country characteristics are included or not. In both cases the augmented specifications (columns (3) and (6)) reveal an interesting additional insight about the relative importance of age and year of birth. Later birth cohorts are associated with significantly lower levels of morale whereas age as such has no effect. This finding corresponds to the descriptive insights of figure 3. Furthermore both augmented specifications also show a significantly positive effect of employment on morale.

Robustness checks support the main findings although with qualification with regard to the time period. Tables (4a) and (4b) include estimation results for the augmented specification for the four waves of the WVS in separation. In these specifications, age and year of birth cannot be added in combination since, for the same point in time, both variables are perfectly collinear. Here, the significant negative effect of the growth of transfers and unemployment on morale characterizes the 1994/1999 and the 1999/2004 waves whereas the coefficients are insignificant in the earlier waves or even significantly 
positive in one case (column (8) regression referring to the earliest wave for the change in transfers).

The probit specification does not exploit the full information available from the answer scale of the benefit morale question (from 1 "never justifiable" up to 10 "always justifiable"). Hence, an ordered probit estimation is added (tables $5 \mathrm{a}$ and $5 \mathrm{~b}$ ) as a further robustness check. For that answer scale a positive sign of a coefficient is associated with a negative impact on morale. The key result, the significant negative impact of a long-run increase in transfers or unemployment on morale, is again supported. With regard to the individual control variables the fuller exploitation of information leads to more significant coefficients: In the ordered probit model confidence in the parliament and income influence morale significantly positive. Again legal origin and federalism show up as relevant country characterics.

First of all these regression show that a number of individual and country characteristics are associated with benefit morale as expected: Individual characteristics like sex, marital status, patriotism exert a robustly significant influence on benefit morale. Many but not all regressions also indicate that employment status and confidence in parliament are also relevant characteristics in this regard. Among the country controls legal origin and decentralization play a role. French (and less robust German) legal origin countries tend to be associated with lower morale than English legal origin countries. The idea that federal structures foster the acceptance of rules is supported by the fact that participants from countries with autonomous regions (according to the classification of the Database of Political Institutions, Beck et al., 2001) show higher levels of morale.

The key finding, however, is that Lindbeck's worries about "hazardous welfare state dynamics" are supported. A country's welfare state history quantified as the long-run increase of transfers or unemployment impacts on the prevalence of welfare state relevant social norms. Here the findings are very similar whether regressions are based on the change in the transfer-GDP-ratio or on the change in unemployment. Hence hypotheses 1 and 2 are supported. The empirical relevance of hypothesis 3 that generational change is the main catalyst receives some though no overwhelming support. All interactions between year of birth and the change in transfers or unemployment are insignificant (columns 4, 7, 18, 21). However, in all augmented regressions which include the full set of country controls and are based on the full sample, the year of birth in contrast to age is significant and exerts a negative impact on morale (columns (3), (6), (17) and (20)). 
Table 3a: Probit regressions for baseline and $\Delta$ social spending, dependent variable: "claiming government benefits to which you are not entitled is never justifiable" (1) versus other answers (0), full sample

\begin{tabular}{|c|c|c|c|c|c|c|c|c|}
\hline & $(1$ & & & & & & ( & \\
\hline & Coefficient & $\mathrm{ME}$ & Coefficient & $\mathrm{ME}$ & Coefficient & $\mathrm{ME}$ & Coefficient. & $\mathrm{ME}$ \\
\hline Constant & $-7,1700$ & & 13.4716 & & $50.0539 * \star \star$ & & 11.8642 & \\
\hline Age & 0.0175 & 0.0066 & 0.0088 & 0.0032 & -0.0097 & -0.0035 & 0.0087 & 0.0032 \\
\hline Year of birth & 0.0036 & 0.0014 & -0.0066 & -0.0024 & $-0.0251^{* \star *}$ & -0.0092 & -0.0058 & -0.0021 \\
\hline Female & $0.1013^{\star \star \star}$ & 0.0381 & $0.0976^{\star \star \star}$ & 0.0358 & $0.0985^{\star \star \star}$ & 0.0361 & $0.0977^{* \star \star}$ & 0.0358 \\
\hline Married & $0.1335^{\star \star *}$ & 0.0505 & $0.1298^{\star \star *}$ & 0.0478 & $0.1331^{* \star *}$ & 0.0490 & $0.1296 * \star \star$ & 0.0477 \\
\hline Employed & 0.0431 & 0.0162 & $0.0970 * \star \star$ & 0.0357 & $0.0662^{* * *}$ & 0.0243 & 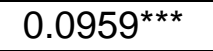 & 0.0353 \\
\hline Religious & -0.0025 & -0.0009 & 0.0105 & 0.0038 & 0.0081 & 0.0030 & 0.0105 & 0.0039 \\
\hline Confidence in Parliament & 0.0075 & 0.0028 & 0.0285 & 0.0104 & 0.0198 & 0.0073 & 0.0283 & 0.0104 \\
\hline Patriotism & $0.1404^{\star \star \star}$ & 0.0528 & $0.1348^{\star \star *}$ & 0.0495 & $0.1065^{\star \star \star}$ & 0.0391 & $0.1348^{\star \star \star}$ & 0.0494 \\
\hline Income & 0.0137 & 0.0052 & 0.0100 & 0.0037 & 0.0123 & 0.0045 & 0.0100 & 0.0037 \\
\hline$\Delta$ Social security benefits & & & $-0.0343^{* \star}$ & -0.0126 & $-0.0463^{\star \star \star}$ & -0.0170 & 0.0412 & 0.1511 \\
\hline Year of birth $x \Delta$ social spending & & & & & & & -0.0002 & -0.0001 \\
\hline Ethnic fractionalization & & & & & -0.3742 & -0.1372 & & \\
\hline latitude & & & & & 0.0151 & 0.0055 & & \\
\hline Legal origin: French & & & & & $-0.3920^{\star \star \star}$ & -0.1470 & & \\
\hline Legal origin: German & & & & & $-0.2135^{\star \star \star}$ & -0.0799 & & \\
\hline Legal origin: Scandinavian & & & & & -0.0504 & -0.0186 & & \\
\hline Tax decentralization & & & & & 0.0024 & 0.0009 & & \\
\hline Autonomous regions & & & & & $0.3838 * \star \star$ & 0.1320 & & \\
\hline Wave dummies included & yes & & yes & & no & & yes & \\
\hline Pseudo $\mathrm{R}^{2}$ & 0.0442 & & 0.0559 & & 0.0608 & & 0.0559 & \\
\hline Prob $>\chi^{2}$ & 0.0000 & & 0.0000 & & 0.0000 & & 0.0000 & \\
\hline Number of observations & 83,130 & & 53,529 & & 53,529 & & 53,529 & \\
\hline
\end{tabular}

Weighted probit estimation allowing for country correlation of errors terms; legal origin: omitted dummy is English legal origin. ME: marginal effect. 
Table 3b: Probit regressions for $\Delta$ unemployment, dependent variable: "claiming government benefits to which you are not entitled is never justifiable" (1) versus other answers (0), full sample

\begin{tabular}{|c|c|c|c|c|c|c|}
\hline & (5) & & (6 & & (7 & \\
\hline & Coefficient & $\mathrm{ME}$ & Coefficient & $\mathrm{ME}$ & Coefficient & $\mathrm{ME}$ \\
\hline Constant & -53.1824 & & $31.4310 * \star \star$ & & -52.2658 & \\
\hline Age & 0.0404 & 0.0147 & -0.0005 & -0.0002 & 0.0404 & 0.0147 \\
\hline Year of birth & 0.0270 & 0.0098 & $-0.0158^{\star \star \star}$ & -0.0058 & 0.0265 & 0.0096 \\
\hline Female & $0.0936 * \star \star$ & 0.0340 & $0.1083^{\star \star \star}$ & 0.0396 & $0.0935^{\star \star \star}$ & 0.0340 \\
\hline Married & $0.1515^{\star \star \star}$ & 0.0554 & $0.1320 * \star \star$ & 0.0485 & $0.1515^{\star \star \star}$ & 0.0554 \\
\hline Employed & 0.0439 & 0.0160 & $0.0604^{\star * \star}$ & 0.0222 & 0.0440 & 0.0160 \\
\hline Religious & 0.0128 & 0.0046 & 0.0067 & 0.0025 & 0.0129 & 0.0047 \\
\hline Confidence in Parliament & 0.0120 & 0.0044 & 0.0144 & 0.0053 & 0.0120 & 0.0044 \\
\hline Patriotism & $0.1210^{\star \star \star}$ & 0.0440 & $0.0968^{\star \star \star}$ & 0.0354 & $0.1212^{\star \star \star}$ & 0.0440 \\
\hline Income & 0.0041 & 0.0015 & $0.0134^{*}$ & 0.0049 & 0.0040 & 0.0015 \\
\hline$\Delta$ Unemployment & $-0.0375^{\star \star \star}$ & -0.0136 & $-0.0264^{* *}$ & -0.0096 & -0.2451 & -0.0890 \\
\hline Year of birth $\times \Delta$ unemployment & & & & & 0.0001 & 0.0000 \\
\hline Ethnic fractionalization & & & -0.1005 & -0.0368 & & \\
\hline Latitude & & & -0.1424 & -0.0521 & & \\
\hline Legal origin: French & & & $-0.3830^{\star *}$ & -0.1428 & & \\
\hline Legal origin: German & & & $-0.1290^{\star}$ & -0.0479 & & \\
\hline Legal origin: Scandinavian & & & 0.0645 & 0.0234 & & \\
\hline Tax decentralization & & & -0.0005 & -0.0002 & & \\
\hline Autonomous regions & & & $0.3165^{\star \star}$ & 0.1101 & & \\
\hline Wave dummies included & yes & & no & & yes & \\
\hline Pseudo $\mathrm{R}^{2}$ & 0.0499 & & 0.0593 & & 0.0499 & \\
\hline Prob $>\chi^{2}$ & 0.0000 & & 0.0000 & & 0.0000 & \\
\hline Number of observations & 64,251 & & 62,208 & & 64,251 & \\
\hline
\end{tabular}

Weighted probit estimation allowing for country correlation of errors terms; legal origin: omitted dummy is English legal origin. ME: marginal effect. 
Table 4a: Probit regressions for $\Delta$ social spending, dependent variable: "claiming government benefits to which you are not entitled is never justifiable" (1) versus other answers (0), separate waves

\begin{tabular}{|c|c|c|c|c|c|c|c|c|}
\hline & \multicolumn{2}{|c|}{ (8) } & \multicolumn{2}{|c|}{ (9) } & \multicolumn{2}{|c|}{ (10) } & \multicolumn{2}{|c|}{ (11) } \\
\hline & \multicolumn{2}{|c|}{ 1981-84 } & \multicolumn{2}{|c|}{ 1989-1993 } & \multicolumn{2}{|c|}{ 1994-1999 } & \multicolumn{2}{|c|}{$1999-2004$} \\
\hline & Coefficient. & ME & Coefficient. & ME & Coefficient. & ME & Coefficient. & $\mathrm{ME}$ \\
\hline Constant & $0.4882^{\star \star \star}$ & & -0.2292 & & $1.5525^{\star \star \star}$ & & -0.4893 & \\
\hline Age & $0.0168^{\star \star \star}$ & 0.0051 & $0.0138^{\star \star \star}$ & 0.0052 & $0.0177^{\star \star \star}$ & 0.0063 & $0.0147^{\star \star \star}$ & 0.0056 \\
\hline Female & $0.1358^{\star \star \star}$ & 0.0413 & $0.0715^{\star \star}$ & 0.0268 & $0.1440^{\star \star \star}$ & 0.0510 & $0.0868^{\star \star \star}$ & 0.0332 \\
\hline Married & $0.1865^{\star \star \star}$ & 0.0578 & $0.1158^{\star \star \star}$ & 0.0436 & $0.1449 * \star \star$ & 0.0516 & $0.1360^{\star \star \star}$ & 0.0522 \\
\hline Employed & $0.1506^{\star \star \star}$ & 0.0463 & 0.0306 & 0.0115 & $0.0637^{\star \star \star}$ & 0.0227 & $0.0758 * \star$ & 0.0291 \\
\hline Religious & 0.0159 & 0.0048 & 0.0097 & 0.0037 & 0.0062 & 0.0022 & $0.0130 * \star$ & 0.0050 \\
\hline Confidence in Parliament & $0.0580 *$ & 0.0176 & 0.0341 & 0.0128 & -0.0175 & -0.0062 & 0.0039 & 0.0015 \\
\hline Patriotism & 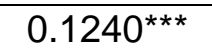 & 0.0377 & $0.1106^{\star \star \star}$ & 0.0415 & 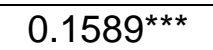 & 0.0564 & $0.0963^{\star \star \star}$ & 0.0369 \\
\hline Income & 0.0086 & 0.0026 & 0.0053 & 0.0020 & $0.0225^{\star \star \star}$ & 0.0080 & $0.0145^{\star \star}$ & 0.0056 \\
\hline$\Delta$ Social security benefits & 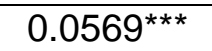 & 0.0173 & -0.0541 & -0.0202 & $-0.0296 * \star \star$ & -0.0105 & $-0.0760 * \star \star$ & -0.0291 \\
\hline Ethnic fractionalization & -0.2037 & -0.0620 & -0.5890 & -0.2208 & $2.0036 * \star \star$ & 0.7104 & -0.3045 & -0.1166 \\
\hline Latitude & $-1.0511^{\star \star \star}$ & -0.3198 & $0.9229 * \star$ & 0.3460 & $-4.7431^{\star \star \star}$ & -1.6817 & 0.5952 & 0.2279 \\
\hline Legal origin: French & $0.0823^{\star \star \star}$ & 0.0244 & -0.2113 & -0.0796 & $-0.2548^{\star \star \star}$ & -0.0943 & 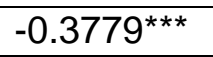 & -0.1455 \\
\hline Legal origin: German & $-0.2318^{\star \star \star}$ & -0.0738 & -0.1141 & -0.0432 & $0.5864^{\star \star \star}$ & 0.1895 & -0.0825 & -0.0318 \\
\hline Legal origin: Scandinavian & $0.1941^{\star \star \star}$ & 0.0563 & -0.3262 & -0.1263 & $1.9767^{\star \star \star}$ & 0.5254 & -0.1112 & -0.0430 \\
\hline Tax decentralization & $-0.0033^{\star \star}$ & -0.0010 & 0.0060 & 0.0023 & $-0.0188^{\star \star \star}$ & -0.0067 & 0.0055 & 0.0021 \\
\hline Autonomous regions & & & $0.4395^{\star \star}$ & 0.1565 & & & $0.4439 * \star \star$ & 0.1600 \\
\hline Pseudo $\mathrm{R}^{2}$ & 0.0806 & & 0.0472 & & 0.0689 & & 0.0661 & \\
\hline Prob $>\chi^{2}$ & 0.0000 & & 0.0000 & & 0.0000 & & 0.0000 & \\
\hline Number of observations & 8,871 & & 18,254 & & 8,541 & & 17,863 & \\
\hline
\end{tabular}

Weighted probit estimation allowing for country correlation of errors terms; legal origin: omitted dummy is English legal origin. ME: marginal effect. 
Table 4b: Probit regressions for $\Delta$ unemployment, dependent variable: "claiming government benefits to which you are not entitled is never justifiable" (1) versus other answers (0), separate waves

\begin{tabular}{|c|c|c|c|c|c|c|c|c|}
\hline & \multicolumn{2}{|c|}{$(12)$} & \multicolumn{2}{|c|}{ (13) } & \multicolumn{2}{|c|}{ (14) } & \multicolumn{2}{|c|}{ (15) } \\
\hline & \multicolumn{2}{|c|}{ 1981-84 } & \multicolumn{2}{|c|}{ 1989-1993 } & \multicolumn{2}{|c|}{ 1994-1999 } & \multicolumn{2}{|c|}{ 1999-2004 } \\
\hline & Coefficient. & ME & Coefficient. & ME & Coefficient. & $\mathrm{ME}$ & Coefficient. & $\mathrm{ME}$ \\
\hline Constant & $1.0834^{\star \star \star}$ & & -0.2148 & & $1.1304^{\star \star \star}$ & & $-0.9116^{\star \star \star}$ & \\
\hline Age & $0.0154^{\star \star \star}$ & 0.0050 & $0.0142^{\star \star \star}$ & 0.0053 & $0.0177^{* \star \star}$ & 0.0063 & $0.0146 * \star \star$ & 0.0056 \\
\hline Female & $0.1303^{* \star \star}$ & 0.0424 & $0.0941^{\star \star \star}$ & 0.0351 & $0.1579 * * \star$ & 0.0561 & $0.0889 * * *$ & 0.0340 \\
\hline Married & $0.1607^{* \star \star}$ & 0.0531 & $0.1076^{\star \star \star}$ & 0.0403 & $0.1477^{\star \star \star}$ & 0.0527 & $0.1392^{\star \star \star}$ & 0.0534 \\
\hline Employed & $0.0882^{\star \star}$ & 0.0289 & 0.0588 & 0.0220 & 0.0586 ** & 0.0209 & $0.0620 * \star$ & 0.0238 \\
\hline Religious & $0.0223^{\star \star \star}$ & 0.0073 & 0.0098 & 0.0036 & -0.0012 & -0.0004 & 0.0119 & 0.0045 \\
\hline Confidence in Parliament & -0.0101 & -0.0033 & 0.0234 & 0.0087 & -0.0044 & -0.0016 & 0.0012 & 0.0004 \\
\hline Patriotism & $0.1075^{\star \star \star}$ & 0.0351 & $0.1078^{\star \star \star}$ & 0.0402 & $0.1375^{\star \star \star}$ & 0.0489 & $0.0820 * \star \star$ & 0.0314 \\
\hline Income & 0.0120 & 0.0039 & 0.0060 & 0.0022 & $0.0229 * * \star$ & 0.0081 & $0.0143^{\star *}$ & 0.0055 \\
\hline$\Delta$ Unemployment & -0.0297 & -0.0097 & 0.0256 & 0.0096 & $-0.0140 * \star \star$ & -0.0050 & $-0.0999 * \star \star$ & -0.0383 \\
\hline Ethnic fractionalization & 0.0939 & 0.0306 & -0.6548 & -0.2441 & $1.5947^{\star \star \star}$ & 0.5668 & -0.2135 & -0.0817 \\
\hline Latitude & $-1.4463^{\star \star \star}$ & -0.4717 & 0.2742 & 0.1022 & $-3.7122^{\star \star \star}$ & -1.3195 & $1.1595^{\star \star}$ & 0.4439 \\
\hline Legal origin: French & $-0.6789 * \star$ & -0.2351 & $-0.3107^{*}$ & -0.1166 & & & 0.1272 & 0.0485 \\
\hline Legal origin: German & $-0.3348 *$ & -0.1167 & -0.0954 & -0.0359 & $0.4355^{\star \star \star}$ & 0.1475 & $0.3448 * *$ & 0.1267 \\
\hline Legal origin: Scandinavian & 0.5438 & 0.1602 & -0.2108 & -0.0805 & $1.4670^{\star \star \star}$ & 0.4152 & 0.0558 & 0.0213 \\
\hline Tax decentralization & -0.0081 & -0.0026 & 0.0068 & 0.0025 & $-0.0163^{* * \star}$ & -0.0058 & 0.0005 & 0.0002 \\
\hline Autonomous regions & 0.2329 & 0.0725 & 0.2044 & 0.0744 & $-0.1781^{\star \star}$ & -0.0654 & $0.3788^{* * \star}$ & 0.1380 \\
\hline Pseudo $\mathrm{R}^{2}$ & 0.0864 & & 0.0472 & & 0.0657 & & 0.0714 & \\
\hline Prob $>\chi^{2}$ & 0.0000 & & 0.0000 & & 0.0000 & & 0.0000 & \\
\hline Number of observations & 13,935 & & 21,049 & & 9,361 & & 17,863 & \\
\hline
\end{tabular}

Weighted probit estimation allowing for country correlation of errors terms; legal origin: omitted dummy is English legal origin. ME: marginal effect. French legal origin dropped in (13) due to missing country observations for that wave. 
Table 5a: Ordered probit regressions for $\Delta$ social spending, dependent variable: "claiming government benefits to which you are not entitled is never justifiable" (1) up to "always justifiable" (10)

\begin{tabular}{|c|c|c|c|c|c|c|}
\hline & $(1$ & & & & & \\
\hline & Coefficient & $\mathrm{ME}$ & Coefficient & $\mathrm{ME}$ & Coefficient & ME \\
\hline Age & -0.0109 & -0.0007 & 0.0087 & 0.0005 & -0.0108 & -0.0007 \\
\hline Year of birth & 0.0030 & 0.0002 & $0.0225^{\star \star \star}$ & 0.0014 & 0.0020 & 0.0001 \\
\hline Female & $-0.0863^{* \star *}$ & -0.0054 & $-0.0846^{\star \star \star}$ & -0.0053 & $-0.0864^{\star \star \star}$ & -0.0054 \\
\hline Married & $-0.1143^{\star * *}$ & -0.0072 & $-0.1182^{\star \star \star}$ & -0.0075 & $-0.1140 * \star \star$ & -0.0072 \\
\hline Employed & $-0.0977^{\star \star \star}$ & -0.0062 & $-0.0610 * \star$ & -0.0039 & $-0.0964^{\star \star \star}$ & -0.0061 \\
\hline Religious & -0.0130 & -0.0008 & $-0.0127^{\star \star}$ & -0.0008 & -0.0131 & -0.0008 \\
\hline Confidence in Parliament & $-0.0541^{* \star *}$ & -0.0034 & $-0.0408^{\star \star}$ & -0.0026 & $-0.0538^{\star \star \star}$ & -0.0034 \\
\hline Patriotism & $-0.1143^{\star \star \star}$ & -0.0072 & $-0.0908^{\star \star \star}$ & -0.0057 & $-0.1142^{\star \star \star}$ & -0.0072 \\
\hline Income & $-0.0145^{\star}$ & -0.0009 & $-0.0167^{*}$ & -0.0011 & $-0.0145^{*}$ & -0.0009 \\
\hline$\Delta$ Social security benefits & $0.0392^{* *}$ & 0.0025 & $0.0502^{\star * *}$ & 0.0032 & -0.4792 & -0.0301 \\
\hline Year of birth $x \Delta$ social spending & & & & & 0.0003 & 0.0000 \\
\hline Ethnic fractionalization & & & 0.3757 & 0.0236 & & \\
\hline Latitude & & & -0.0513 & -0.0032 & & \\
\hline Legal origin: French & & & $0.4065^{\star \star \star}$ & 0.0266 & & \\
\hline Legal origin: German & & & $0.1828 * \star$ & 0.0119 & & \\
\hline Legal origin: Scandinavian & & & -0.0006 & 0.0000 & & \\
\hline Tax decentralization & & & -0.0016 & -0.0001 & & \\
\hline Autonomous regions & & & $-0.3584^{\star \star}$ & -0.0205 & & \\
\hline Wave dummies included & yes & & No & & yes & \\
\hline Pseudo $\mathrm{R}^{2}$ & 0.0287 & & 0.0320 & & 0.0288 & \\
\hline Prob $>\chi^{2}$ & 0.0000 & & 0.0000 & & 0.0000 & \\
\hline Number of observations & 53,529 & & 53,529 & & 53,529 & \\
\hline
\end{tabular}

Weighted ordered probit estimation allowing for country correlation of errors terms; legal origin: omitted dummy is English legal origin. ME: marginal effect for answer category 5. 
Table 5b: Ordered probit regressions for $\Delta$ unemployment, dependent variable: "claiming government benefits to which you are not entitled is never justifiable" (1) up to "always justifiable" (10)

\begin{tabular}{|c|c|c|c|c|c|c|}
\hline & \multicolumn{2}{|c|}{ (19) } & \multicolumn{2}{|c|}{ (20) } & \multicolumn{2}{|c|}{$(21)$} \\
\hline & Coefficient & ME & Coefficient & $\mathrm{ME}$ & Coefficient & ME \\
\hline \multicolumn{7}{|l|}{ Constant } \\
\hline Age & $-0.0344^{*}$ & -0.0021 & -0.0015 & -0.0001 & $-0.0344^{\star}$ & -0.0022 \\
\hline Year of birth & -0.0222 & -0.0014 & $0.0120 * \star \star$ & 0.0008 & -0.0218 & -0.0014 \\
\hline Female & $-0.0832^{\star \star \star}$ & -0.0052 & $-0.0938^{\star \star \star}$ & -0.0060 & $-0.0831^{* \star \star}$ & -0.0052 \\
\hline Married & $-0.1349 * \star \star$ & -0.0085 & $-0.1176^{\star \star \star}$ & -0.0076 & $-0.1350 * \star \star$ & -0.0085 \\
\hline Employed & -0.0479 & -0.0030 & $-0.0548^{\star \star}$ & -0.0035 & -0.0480 & -0.0030 \\
\hline Religious & -0.0155 & -0.0010 & $-0.0109 *$ & -0.0007 & -0.0156 & -0.0010 \\
\hline Confidence in Parliament & $-0.0347^{* *}$ & -0.0022 & $-0.0345^{\star}$ & -0.0022 & $-0.0348^{\star \star}$ & -0.0022 \\
\hline Patriotism & $-0.1021^{\star \star \star}$ & -0.0064 & $-0.0822^{\star \star \star}$ & -0.0053 & $-0.1024^{\star \star \star}$ & -0.0064 \\
\hline Income & -0.0090 & -0.0006 & $-0.0177^{* \star}$ & -0.0011 & -0.0090 & -0.0006 \\
\hline$\Delta$ Unemployment & $0.0397^{* * *}$ & 0.0025 & $0.0277^{* *}$ & 0.0018 & 0.2740 & 0.0171 \\
\hline Year of birth $x \Delta$ unemployment & & & & & -0.0001 & 0.0000 \\
\hline Ethnic fractionalization & & & 0.0809 & 0.0052 & & \\
\hline Latitude & & & 0.0857 & 0.0055 & & \\
\hline Legal origin: French & & & $0.3965^{\star \star}$ & 0.0261 & & \\
\hline Legal origin: German & & & 0.0897 & 0.0058 & & \\
\hline Legal origin: Scandinavian & & & -0.1013 & -0.0063 & & \\
\hline Tax decentralization & & & 0.0014 & 0.0001 & & \\
\hline Autonomous regions & & & $-0.3040 * \star$ & -0.0180 & & \\
\hline Wave dummies included & yes & & no & & yes & \\
\hline Pseudo $\mathrm{R}^{2}$ & 0.0258 & & 0.0311 & & 0.0258 & \\
\hline Prob $>\chi^{2}$ & 0.0000 & & 0.0000 & & 0.0000 & \\
\hline Number of observations & 64,251 & & 62,208 & & 64,251 & \\
\hline
\end{tabular}

Weighted ordered probit estimation allowing for country correlation of errors terms; legal origin: omitted dummy is English legal origin. ME: marginal effect for answer category 5 . 


\section{Conclusions}

The presented empirical findings clearly indicate that Assar Lindbeck's theory on selfdestructive welfare state dynamics has empirical backing. Social norms which safeguard the welfare state's stability and limit its costs appear to be influenced by the welfare state's history. Specifically, transfer expansion or increasing unemployment tend to be associated with a larger readiness of the country's population to cheat on benefits.

Some remarks on the limits of the presented insights are necessary. Although the findings support the view that the welfare state tends to erode benefit morale they do not yet allow for a clear identification of exact channels. The hypothesis that generational change is an important precondition for the negative ethical influences of the welfare state is not supported directly since the interactions of year of births with the welfare state proxies have not been significant. However, in a number of regressions the year of birth as such showed significance with later birth cohorts showing a larger sympathy for the unjustified claim of benefits. However, the question still remains unresolved where this deterioration originates from the evolution of the welfare state or from other generation specific characteristics which are not covered by the included individual characteristics. Both models based on the long-run change in unemployment on the one hand and transfers on the other hand have led to very similar results making it hard to discriminate between both. This is not surprising given the fact that both transfer growth and unemployment increases are mutually interdependent and highly correlated. Hence it is not possible to judge from the results whether it is the larger familiarity with unemployment (independent from transfer offers) or a larger welfare state generosity which is at the heart of the problem.

The presented empirics with regard to the long-run determinants of benefit morale have important implications for the design of welfare state reforms. Furthermore, they highlight the risk that conventional empirical approaches to measure the incentive effects of welfare state arrangements may underestimate the strength of incentive effects in the long-run.

With regard to welfare state reforms the conclusion is that the large variance in benefit morale must not be ignored in the design of reform options for the welfare state. An imitation of institutions which have proven viable in countries with high ethical standards can fail in a country with low ethical standards. Therefore, different social norms have to be taken into account in reflections on imitation strategies based on learning from successful countries. A further conclusion is that the problem of a potential "welfare state overshoot" as identified theoretically by Lindbeck may indeed be relevant empirically: If only short-run incentive effects are accounted for in the decision on the build-up of 
welfare state arrangements then the long-run costs of the welfare state are underestimated. The decision based on the short-run calculus will then be more generous than it would be the case if the optimizing calculus was based on a full account of all (also the long-run) behavioural reactions which result from the welfare state's gradual impact on social norms.

Besides these economic policy insights methodological conclusions emerge. Standard microeconometric approaches targeted at the quantification of incentive effects are based on the implicit assumption of stable social norms. E.g., in the context of labour markets normative restrictions with regard to the take-up of social benefits are treated as exogenously given. This study stresses the problem that this ceteris paribus assumption is empirically not valid. If transfers undermine those norms which support a reluctant takeup of government benefits then the negative effects of transfers on labour supply are more pronounced than it can be measured in the standard microeconometric exercises.

\section{References}

Alesina, Alberto, Arnaud Devleeschauwer, William Easterly, Sergio Kurlat and Romain Wacziarg (2003): Fractionalization, Journal of Economic Growth, 8, 155-94.

Alesina, Alberto and Ferrara, Eliana La (2005): Ethnic Diversity and Economic Performance, Journal of Economic Literature, 43 (3), 762-800.

Algan, Yann and Pierre Cahuc (2005): Civic Attitudes and the Design of Labor Market Institutions, Which Countries Can Implement the Danish Flexicurity Model, DEPREMAP Discussion Paper, No. 0517, Paris.

Alm, James and Benno Torgler (2006): Culture Differences and Tax Morale in the United States and Europe, Journal of Economic Psychology, 27 (2), 224-246.

Beck, Thorsten, George Clarke, Alberto Groff, Philip Keefer and Patrick Walsh (2001): New tools in comparative political economy: The Database of Political Institutions, World Bank Economic Review, 15 (1), 165-176.

Djankov, Simeon, Rafael La Porta, Florencio Lopez-de-Silanes and Andrei Shleifer (2003): The New Comparative Economics, Journal of Comparative Economics, 31(4), 595-619.

European Values Study Foundation and World Values Survey Association (2006): European and World Values Surveys Four-Wave Integrated Data File, 19812004, v.20060423, 2006.

Halla, Martin and Friedrich G. Schneider (2005): Taxes and Benefits: Two Distinct Options to Cheat on the State?, Department of Economics working paper No 2005-05, Johannes Kepler University Linz. 
La Porta, Rafael, Florencio Lopez-de-Silanes, Andrei Shleifer, and Robert Vishny (1999): The Quality of Government, Journal of Law, Economics and Organization, 15, 222-279.

Lindbeck, Assar (1995a): Hazardous Welfare-State Dynamics, American Economic Review, Papers and Proceedings, 85 (2), 9-15.

Lindbeck, Assar (1995b): Welfare State Disincentives with Endogenous Habits and Norms, Scandinavian Journal of Economics, 97 (4), 477-494.

Lindbeck, Assar, Nyberg, Sten and Jörgen W. Weibull (1999): Social Norms and Economic Incentives in the Welfare State, The Quarterly Journal of Economics, CXIV (1), 1- 35.

Lindbeck, Assar and Sten Nyberg (2006): Raising Children to Work Hard: Altruism, Work Norms, and Social Insurance, The Quarterly Journal of Economics, November, 1473-1503.

Parsons, Talcott (1952): The Social System, Tavistock Publications, London.

Stegarescu, Dan (2005): Public sector decentralisation: measurement concepts and recent international trends, Fiscal studies, 26 (3), 301-333

Sugden, Robert (1986): The Economics of Rights, Cooperation and Welfare, Basic Blackwell, Oxford.

Torgler, Benno (2002): Speaking to Theorists and Searching for Facts: Tax Morale and Tax Compliance in Experiments, Journal of Economic Surveys, 16 (5), 657-683.

Torgler, Benno (2004): Tax Morale and Institutions, YCIAS Working Paper, LP05, Yale Center for International and Area Studies, New Haven.

Torgler, Benno and Jan Werner (2005): Tax Morale and Fiscal Autonomy: Evidence from Germany, Public Finance and Management, 5 (4), 460-485. 


\section{Appendix}

Table 1: Variable definitions and sources

\begin{tabular}{|c|c|c|}
\hline Variable & Definition & Source \\
\hline Age & Age in years & EWVS \\
\hline Year of birth & Year of birth & EWVS \\
\hline Patriotism & $\begin{array}{l}\text { "Proud of nationality" from "not at } \\
\text { all" (-4) to "very proud" }(-1)\end{array}$ & EWVS \\
\hline Employed & $\begin{array}{l}\text { Full time, part time or self- } \\
\text { employed versus retired, } \\
\text { housewife, students, unemployed } \\
\text { or other }\end{array}$ & EWVS \\
\hline Income & 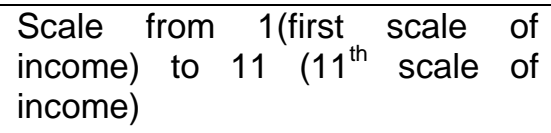 & EWVS \\
\hline Religious & $\begin{array}{l}\text { Frequency of attendance of } \\
\text { religious services from }-8 \text { (never) } \\
\text { to more than once a week (-1) }\end{array}$ & EWVS \\
\hline Financial satisfaction & $\begin{array}{l}\text { Scale from } 1 \text { (dissatisfied) to } 10 \\
\text { (satisfied) }\end{array}$ & EWVS \\
\hline Confidence in parliament & $\begin{array}{l}\text { Scale from "none at all" (-4) to "a } \\
\text { great deal" }(-1)\end{array}$ & EWVS \\
\hline$\Delta$ Social security benefits & $\begin{array}{l}\text { Change of social spending over } \\
20 \text { years in percentage points of } \\
\text { GDP }\end{array}$ & $\begin{array}{lll}\text { OECD } & \text { Economic } & \text { Outlook } \\
\text { Database } & & \end{array}$ \\
\hline$\Delta$ Unemployment & $\begin{array}{l}\text { Change of unemployment rate } \\
\text { over } 20 \text { years in percentage } \\
\text { points }\end{array}$ & $\begin{array}{lll}\text { OECD } & \text { Economic } & \text { Outlook } \\
\text { Database } & \end{array}$ \\
\hline Ethnic fractionalization & $\begin{array}{l}\text { One minus Herfindahl index of } \\
\text { ethnic group shares }\end{array}$ & Alesina et al. (2003) \\
\hline Latitude & Latitude of country capital & $\begin{array}{l}\text { Djankov et al. (2003), from CIA } \\
\text { factbook }\end{array}$ \\
\hline Legal origin & Legal origin & La Porta et al., 1999 \\
\hline Tax decentralization & $\begin{array}{l}\text { Share of regional tax revenues } \\
\text { from own autonomous taxes and } \\
\text { total tax reveneu }\end{array}$ & Stegarescu (2005) \\
\hline Autonomous regions & $\begin{array}{l}\text { Dummy on existence of } \\
\text { autonomous regions }\end{array}$ & Beck et al. (2001) \\
\hline
\end{tabular}

EWVS: European Values Study Foundation and World Values Survey Association (2006). 
Table 2: Country coverage of WVS over four waves,

Selection: Industrial countries, answers on benefit morale question available

\begin{tabular}{|l|r|r|}
\hline Country & Nb. of observations & Percent of total \\
\hline Australia & 3,248 & 2.79 \\
\hline Austria & 2,941 & 2.53 \\
\hline Belgium & 5,651 & 4.86 \\
\hline Canada & 4,871 & 4.19 \\
\hline Czech republic & 6,004 & 5.17 \\
\hline Denmark & 3,214 & 2.77 \\
\hline Finland & 2,533 & 2.18 \\
\hline France & 3,723 & 3.2 \\
\hline Greece & 1,085 & 0.93 \\
\hline Hungary & 3,983 & 3.43 \\
\hline Iceland & 2,571 & 2.21 \\
\hline Ireland & 3,167 & 2.73 \\
\hline Italy & 5,265 & 4.53 \\
\hline Japan & 4,277 & 3.68 \\
\hline Republic of Korea & 2,166 & 1.86 \\
\hline Luxembourg & 1,147 & 0.99 \\
\hline Mexico & 4,987 & 4.29 \\
\hline Netherlands & 3,211 & 2.76 \\
\hline New Zealand & 1,149 & 0.99 \\
\hline Norway & 3,381 & 2.91 \\
\hline Poland & 4,060 & 3.49 \\
\hline Portugal & 2,128 & 1.83 \\
\hline Slovakia & 3,948 & 3.4 \\
\hline Spain & 9,653 & 8.31 \\
\hline Sweden & 3,975 & 3.42 \\
\hline Switzerland & 2,517 & 2.17 \\
\hline Turkey & 2,213 & 1.9 \\
\hline Great Britain & 3,619 & 3.11 \\
\hline United States & 6,822 & 5.87 \\
\hline West Germany & 5,404 & 4.65 \\
\hline East Germany & 3,306 & 2.84 \\
\hline Total & $\mathbf{1 1 6 , 2 1 9}$ & $\mathbf{1 0 0}$ \\
\hline & & \\
\hline & & \\
\hline
\end{tabular}

